\title{
Response of Four Species of Tropical Timber Seedlings to Urea and Folivert Fertilisers in Nursery.
}

\author{
Egbe Enow Andrew ${ }^{\mathbf{1} \mathbf{2}^{*}}$ Tata Blessing Limbi ${ }^{1}$ and Enow Elsie Ayamoh ${ }^{1}$
}

${ }^{1}$ Department of Botany and Plant Physiology, University of Buea, P.O.BOX 63 Buea, Cameroon.

${ }^{2}$ Faculty of Agriculture and Veterinary Medicine, University of Buea, Cameroon

egbe1@yahoo.com

\begin{abstract}
This study explores the effects of different levels of urea and folivert (composite fertilizer) on seedlings growth and chlorophyll concentration of Albizia zygia, Blighia welwitschii, Lophira alata and Pterocarpus soyauxii. The rate of fertilizer application per $5.87 \mathrm{~kg}$ pot with topsoil was 3,6 , and $9 \mathrm{~g}$ of both urea and composite fertilizer and a control (top soil only) and it was a complete randomized design. Results indicated that plants treated with $3 \mathrm{~g}$ of urea produced the highest number of leaves in Albizia zygia seedlings only while $9 \mathrm{~g}$ of composite fertilizer had the best growth performance in all the other growth variables. Albizia zygia and Blighia welwitschii, seedlings had the best results in soil treated with $6 \mathrm{~g}$ of composite fertilizer, while Lophira alata and Pterocarpus soyauxii seedlings showed best growth in soils treated with $9 \mathrm{~g}$ of composite fertilizers for all other parameters. Seedlings of species supplied with $9 \mathrm{~g}$ of urea gave poorest growth performance. Low root/shoot ratios were obtained for all seedlings except for those of Albizia zygia treated with 6 and $9 \mathrm{~g}$ of urea that had root/shoot ratios greater than 1.0. The effect of fertilizers on chlorophyll concentration was significantly different only for $L$. alata $(P=0.05)$. This study therefore brings to light the need to fertilize timber tree seedlings in order to improve on their early growth performances in the field and high doses of nitrogen should be discourage.
\end{abstract}

Key words: Chlorophyll, fertilizers, forest dynamics, growth, timber seedlings.

\section{INTRODUCTION}

Plants are extremely important to people throughout the world; since they are a major source of food, raw materials for clothing, shelter and primary health care. These needs are growing rapidly because of a growing world population, increasing incomes and urbanization. Wood is an organic material that has been used as an important construction material since humans began building shelters, houses, boats, bridges etc. Tropical timbers are preferred as a source of wood because of their natural durability and good working properties. Tree species qualify as timber when their boles grow very tall before producing branches (Miller and Wiedenhoeft, 2002) and with a diameter at breast height of not less than $60 \mathrm{~cm}$.

Besides their uses as timber, other parts of these plants are used as medicine by the local communities (Egbe et $a l ; 2012 a)$. Some of the trees produce fruits which are eaten by wildlife and man and also serve as habitat for other organisms, and are used in cultural settings. Forests recharges watersheds protect soil resources, store carbon in biomass and maintain the delicate composition of the atmosphere (Repetto, 1990). Tropical forests house much terrestrial biodiversity and are home to at least 50 million forest inhabitants worldwide (Côomes et al., 2008), and these populations are threatened by unsustainable land and resource use. The immediate causes of deforestation include agriculture, fuel wood collection, logging, mining and industrial development (De Capua 2005). The highest rate of deforestation occurs in Brazil within whose borders lies about $40 \%$ of the Amazon rainforest, on which over 23 million people are dependent for their livelihoods. The Democratic Republic of Congo embraces about $50 \%$ of the vast Congo Basin rainforest with about 40 million people dependent to some degree, and despite serious abuses of logging, a greater share of the country's forest is relatively undisturbed due to the undeveloped road infrastructure (FAO, 2005). According to FAO (2005) estimates, deforestation rates in Cameroon average 0.6 \% per year. The greatest problem of forest regeneration projects is to have good planting material or seedlings, and this can be achieved by fertilization of the seedlings in nursery. There has been global interest in optimising fertilizer application in the nursery for effective nutrient storage by the 
seedling (Li et al., 2014). Furthermore, Uscola et al (2015) note that ideal fertilization regime promotes seedling growth, nutrient loading without toxic effects while Wang et al (2015) reported that though fertilization of seedlings enhances growth and nutrient loading, field responses is always variable and therefore site-specific considerations should be taken in nursery fertilization. The amount of nitrogen and its time of application might influence plant morphology, nutrient availability and net photosynthesis (Zhao et al., 2008) and Harper (1974) observed that intermediate nitrogen levels increase seedling biomass, root length and its surface area while root growth was reduced for both high and low levels of fertilization. It was recorded by Well (2007) that excessive concentration of nitrogen has a potential effect on root damage. Focho et al (2011) noted small doses of nitrogen and phosphorus stimulate cell differentiation and multiplication leading to increase of seedling height and this was also reported by Hoque et al (2004a) for Michelia champaca seedlings. High doses of P and especially $\mathrm{N}$ is said to affect the uptake of other important nutrients from the soil and also retards $\mathrm{N}$-storage (Villar-Salvador et al., 2015; Jose 2003; Landis et al., 1989). The use of fertilizers to improve on seedling stock in nursery is pertinent for tropical timber species as most of them have very slow growth rates. There is little or no documented information on the response of these four tropical timber species to fertilization in the nursery. Since nutrient requirement for each species varies, it would provide a baseline information for the production of high-quality seedlings of these species which could be used for afforestation, reforestation programmes or enrichment planting.

\section{Materials and methods}

\section{Study site.}

This study was carried out in the shade house (87.6\% full sunlight, measured with digital Luxmetre, (MS 6610 Mastech $^{\oplus}$ ) of the Department of Botany and Plant Physiology in the University of Buea. This area is located in the Southwest Region of Cameroon between latitude $3^{0} 57^{1}$ and $4^{0} 27^{\prime} \mathrm{N}$ and longitude $8^{0} 58^{1}$ and $9^{0} 25^{\prime} \mathrm{E}$. (Tchouto,1997). Buea, is on the eastern slope of Mount Cameroon and has a humid tropical climate with an annual rainfall of about $2800 \mathrm{~mm}$, most of which is received between June and September (Egbe et al., 2012b). The mean annual temperature is $28^{\circ} \mathrm{C}$ while the relative humidity is about $86 \%$. Buea is mountainous with thick and evergreen forest vegetation and transition changes along altitudinal gradient. The soil type is basically volcanic, rich in mineral content and hence suitable for agriculture. Agriculture is the major activity in this region and this is done mostly as slash and burn by small scale farmers while established commercial plantations of rubber, oil palm and banana are carried out by the Cameroon Development Co-operation (CDC).

\section{Methods}

\section{Experiment 1. The effects of fertilizers on seedling growth of four timber species}

Seeds of Albizia zygia, Blighia welwitschii and Pterocarpus soyauxii were collected from the Limbe Botanic Gardens. Seedlings were raised from these seeds in nursery. Lophira alata wildlings of less than 6 weeks old were used for this experiment.

Top soil was collected from fallow land which was an oil palm plantation of the Cameroon Development Cooperation (CDC). The land had not experience heavy chemical fertilizer application for five years. The soil collected was air-dried and all roots, stems and other organic materials were removed. The soil was put into 5 $L$ pots $(5.87 \mathrm{~kg}$ of soil). The potted seedlings of the different species were supplied with the following seven treatments: Urea fertilizer $N_{1}=3 g, N_{2}=6 g, N_{3}=9 g$; Composite fertilizer $C_{1}=3 g, C_{2}=6 g, C_{3}=9 g$ and topsoil only $=\mathrm{N}_{0} \mathrm{P}_{0}$ (control). The Composite fertilizer (Folivert is composed of $11 \%$ Nitrogen, $46 \%$ Phosphorus, $14 \%$ Potassium oxide, $0.8 \%$ Manganese oxide, $0.09 \%$ Boron, 0.005\% Copper, $0.1 \%$ Iron, 0.05\% Manganese, $0.2 \%$ Molybdenum and $0.05 \%$ Zinc).

A total of 356 seedlings were used; 84 seedlings per species were labelled with Impress-O-Tags with respect to the different treatments. There were three replicates per treatment in complete randomized design. Soil samples at $0-10 \mathrm{~cm}$ dept were also collected from the same site using a steel corer and this was air-dried and 
sieved using a $2 \mathrm{~mm}$ sieve and labelled for routine chemical analyses for macronutrients as described by Kanwar et al (2014). The chemical properties of the soil are shown in Table 1.

Table 1. Chemical composition of topsoil used for fertilizer Experiment

\begin{tabular}{|c|c|}
\hline Element & Concentrations \\
\hline Organic carbon & $2.59 \%$ \\
\hline Total nitrogen & $0.12 \%$ \\
\hline Potassium & $0.10 \mathrm{cmol} \backslash \mathrm{kg}$ \\
\hline Phosphorus & $24 \mathrm{mg} / \mathrm{kg}$ \\
\hline pH (H2O) & 5.19 \\
\hline pH (Kcl) & 4.24 \\
\hline Sodium & $0.02 \mathrm{cmol} / \mathrm{kg}$ \\
\hline Magnesium & $0.34 \mathrm{cmol} \backslash \mathrm{kg}$ \\
\hline Calcium & $1.29 \mathrm{cmol} \backslash \mathrm{kg}$ \\
\hline Aluminum & $0.76 \mathrm{cmol} \backslash \mathrm{kg}$ \\
\hline CEC & $1.58 \mathrm{cmol} \backslash \mathrm{kg}$ \\
\hline C/N & 21.58 \\
\hline
\end{tabular}

\section{Assessment of growth parameters}

The following morphological parameters of the plants were assessed at two weeks intervals for 16 weeks. The height was measured from soil surface to shoot apex with a meter rule, to the nearest $0.1 \mathrm{~cm}$. Seedling collar diameter was measured below the first internodes with an electronic calliper (Shenzhen ${ }^{\circledR}$ G02022615) to the nearest $0.1 \mathrm{~mm}$ while the number of leaves of each species was evaluated by counting. At the end of the experiment, leaves were harvested and the leaf area measured with a leaf area meter model Device D-T Cambridge England. The leaf area of Albizia zygia was not assessed because of the overlapping nature of its leaflets.

At the end of the experiments, roots of the seedlings were carefully removed for each treatment and washed repeatedly to remove all soil particles, blotted gently with tissue paper to remove any free surface moisture. The seedlings were then partitioned into leaves, stems and roots, their fresh weights taken using electronic balance (Ohaus Scout TM Pro) to the nearest $0.01 \mathrm{~g}$. These were oven dried at $72^{\circ} \mathrm{C}$ to constant weight and allowed to cool in a desiccator. Their dry weights were measured with sensitive balance and values recorded.

\section{Experiment 2. The effect of fertilizer treatment on chlorophyll concentration of leaves}


Fresh leaves were harvested from the seedlings (second from the top) in the different treatments and these were rinsed and disinfected with $20 \%$ alcohol for 5 minutes and later rinsed with distilled water three time to remove the ethanol. Fourteen grams of fresh leaves were weighed on an electric balance and macerated in a sterilized crucible. $96 \%$ methanol was added and the mixture homogenized and then poured into $14 \mathrm{ml}$ falcon tubes and left for 20 hours for complete extraction to occur. The homogenate was centrifuged at 2500rpm for ten minutes in a Beckman centrifuge (Model TJ-6). The supernatant was decanted and without delay, its absorbance was measured at $662 \mathrm{~nm}$ and $645 \mathrm{~nm}$ in a spectrophotometer (Beckman Du 530) and results recorded and calculations carried out as described by Zhang et al., 2009.

$\mathrm{Chl}-\mathrm{a}=12.72 \mathrm{~A} 662-2.59 \mathrm{~A} 645$

Chl-b = 22.9A645 - 4.67A662

Chl-t= 20.31 A645 + 8.05 A662 $\approx 0$

Total chlorophyll $=$ chl-a + chl-b + chl-t

Where $\mathrm{Chl}-\mathrm{a}=$ chlorophyll $\mathrm{a}, \mathrm{Chl}-\mathrm{b}=$ chlorophyll $\mathrm{b}, \mathrm{Chl}-\mathrm{t}=$ total carotenoids, $\mathrm{A} 662=$ absobance at $662 \mathrm{~nm}$ wave length, $A 645=$ absorbance at $645 \mathrm{~nm}$ wave length

\subsection{Data analyses}

The data was tested for homogeneity using Komorauve test after which Analysis of Variance was carried out on the resulting data using the MINITAB Version 15 statistical package. All analyses were carried out at 95 and $99 \%$ confidence interval. Multiple comparisons were done using the Tukey HSD test. One-way analysis of variance was carried out for each species since their rate of germination and growth varied before treatments were applied.

\section{RESULTS}

\section{The effect of fertilizer treatments on the growth of Albizia zygia seedlings.}

After sixteen weeks, the tallest seedlings of Albizia zygia were those treated with $6 \mathrm{~g}$ of composite fertilizer, 23.65 $\mathrm{cm}$ and the shortest were those treated with $9 \mathrm{~g}$ of urea $(3.3 \mathrm{~cm})$ as shown in Table 2. There were significant differences between the treatments at $P=0.05$. Albizia zygia seedlings treated with $6 \mathrm{~g}$ of composite fertilizer had the highest collar diameter of $3.85 \mathrm{~mm}$ and the least of $1.10 \mathrm{~mm}$ in seedlings supplied with $9 \mathrm{~g}$ of urea. The highest number of leaves (39) was registered in seedlings supplied with $3 \mathrm{~g}$ of urea treatment and the least (5) in those seedlings that had $9 \mathrm{~g}$ of urea and there were significant differences between treatments at $\mathrm{P}=0.05$. 
Table 2. The effects of fertilizer treatments on Albizia zygia seedlings

\begin{tabular}{|c|c|c|c|c|c|c|c|c|}
\hline \multirow[b]{2}{*}{ Treatment } & \multirow[b]{2}{*}{ Height $(\mathrm{cm})$} & \multirow[b]{2}{*}{$\begin{array}{l}\text { Collar } \\
\text { diameter }(\mathrm{cm})\end{array}$} & \multicolumn{4}{|c|}{ Mean growth characteristics } & \multirow[b]{2}{*}{$\begin{array}{l}\text { Total } \\
\text { biomass } \\
\text { (g) }\end{array}$} & \multirow[b]{2}{*}{$\begin{array}{l}\text { Root/Shoot } \\
\text { Ratio }\end{array}$} \\
\hline & & & $\begin{array}{l}\text { Leaf } \\
\text { number }\end{array}$ & $\begin{array}{l}\text { Dry Weight } \\
\text { leaves (g) }\end{array}$ & $\begin{array}{l}\text { Dry Weight } \\
\text { Stem (g) }\end{array}$ & $\begin{array}{l}\text { Dry Weight } \\
\text { of Roots (g) }\end{array}$ & & \\
\hline $3 g$ urea & 10.0 & 3.00 & 39.00 & 1.25 & 0.24 & 1.16 & 2.65 & 0.78 \\
\hline $6 \mathrm{~g}$ urea & 3.45 & 1.45 & 6.00 & 0.06 & 0.14 & 0.86 & 1.06 & 4.3 \\
\hline $9 g$ urea & 3.30 & 1.10 & 5.00 & 0.03 & 0.01 & 0.05 & 0.09 & 1.25 \\
\hline 3g composite & 9.50 & 3.15 & 24.00 & 0.99 & 0.12 & 0.80 & 1.91 & 0.72 \\
\hline $6 \mathrm{~g}$ composite & 23.65 & 3.85 & 38.00 & 2.63 & 1.79 & 2.48 & 6.90 & 0.56 \\
\hline 9 Composite & 6.05 & 3.20 & 27.00 & 1.45 & 0.48 & 1.10 & 3.03 & 0.57 \\
\hline Control & 5.60 & 2.10 & 16.00 & 1.09 & 0.23 & 0.80 & 2.12 & 0.61 \\
\hline$H S D \leq 0.05$ & 4.70 & ns & 9.00 & ns & ns & ns & ns & 0.42 \\
\hline
\end{tabular}

ns: Not significantly differently at $P=0.0$ 
Table 3. The effect of fertilizer treatments on Blighia welwitschii seedlings

\begin{tabular}{|c|c|c|c|c|c|c|c|c|c|}
\hline \multicolumn{10}{|c|}{ Mean Growth Characteristics } \\
\hline Treatment & $\begin{array}{l}\text { Height } \\
\text { (cm) }\end{array}$ & $\begin{array}{l}\text { Collar } \\
\text { diameter } \\
\text { (cm) }\end{array}$ & $\begin{array}{l}\text { Leaf } \\
\text { number }\end{array}$ & $\begin{array}{l}\text { Leaf } \\
\text { area } \\
\left(\mathrm{cm}^{2}\right)\end{array}$ & $\begin{array}{l}\text { Dry } \\
\text { Weight } \\
\text { leaves (g) }\end{array}$ & $\begin{array}{l}\text { Dry } \\
\text { Weight } \\
\text { stem (g) }\end{array}$ & $\begin{array}{l}\text { Dry Weight } \\
\text { Roots (g) }\end{array}$ & $\begin{array}{l}\text { Total } \\
\text { biomass } \\
\text { (g) }\end{array}$ & $\begin{array}{l}\text { Root/Shoot } \\
\text { Ratio }\end{array}$ \\
\hline $3 g$ urea & 18.05 & 3.97 & 10.00 & 97.76 & 2.10 & 1.33 & 1.67 & 5.40 & 0.49 \\
\hline $6 \mathrm{~g}$ urea & 17.95 & 4.00 & 12.00 & 89.22 & 1.73 & 1.77 & 1.70 & 5.22 & 0.49 \\
\hline $9 g$ urea & 13.80 & 2.80 & 9.00 & 86.73 & 1.15 & 1.12 & 1.19 & 3.46 & 0.52 \\
\hline $3 g$ composite & 16.43 & 4.10 & 10.00 & 119.40 & 3.37 & 2.17 & 2.61 & 8.36 & 0.47 \\
\hline $6 \mathrm{~g}$ composite & 18.27 & 3.97 & 12.00 & 124.01 & 4.10 & 1.81 & 2.45 & 9.59 & 0.42 \\
\hline 9g composite & 19.73 & 4.30 & 16.00 & 140.06 & 5.10 & 3.06 & 4.51 & 12.67 & 0.55 \\
\hline Control & 16.50 & 4.23 & 11.00 & 111.47 & 4.06 & 2.26 & 3.27 & 8.15 & 0.52 \\
\hline $\mathrm{HSD} \leq 0.05$ & 5.54 & 2.15 & 7.00 & 54.67 & 4.01 & 1.90 & ns & ns & ns \\
\hline
\end{tabular}

ns: Not significantly differently at $\mathrm{P}=0.0$

Table 4 The effect of fertilizer treatments on Lophira alata seedlings 


\begin{tabular}{|c|c|c|c|c|c|c|c|c|c|}
\hline Treatment & $\begin{array}{l}\text { Height } \\
(\mathrm{cm})\end{array}$ & $\begin{array}{l}\text { Collar } \\
\text { diameter } \\
\text { (cm) }\end{array}$ & $\begin{array}{l}\text { Leaf } \\
\text { number }\end{array}$ & $\begin{array}{l}\text { Leaf } \\
\text { area } \\
\left(\mathrm{cm}^{2}\right)\end{array}$ & $\begin{array}{l}\text { Dry Weight } \\
\text { leaves(g) }\end{array}$ & $\begin{array}{l}\text { Dry Weight } \\
\text { stem (g) }\end{array}$ & $\begin{array}{l}\text { Dry Weight } \\
\text { Roots (g) }\end{array}$ & $\begin{array}{l}\text { Total } \\
\text { biomass } \\
\text { (g) }\end{array}$ & $\begin{array}{l}\text { Root/Shoot } \\
\text { Ratio }\end{array}$ \\
\hline $3 g$ urea & 21.47 & 1.37 & 3.00 & 10.29 & 0.08 & 0.50 & 0.61 & 1.19 & 1.05 \\
\hline $6 g$ urea & 18.40 & 1.50 & 3.00 & 8.88 & 0.18 & 0.39 & 0.44 & 1.01 & 0.77 \\
\hline 9g urea & 16.95 & 1.08 & 2.00 & 7.92 & 0.05 & 0.36 & 0.38 & 0.79 & 0.79 \\
\hline 3g composite & 21.07 & 1.37 & 6.00 & 12.43 & 0.17 & 0.56 & 0.41 & 1.14 & 0.61 \\
\hline $6 \mathrm{~g}$ composite & 22.00 & 1.73 & 7.00 & 21.35 & 0.35 & 0.62 & 0.45 & 1.42 & 0.46 \\
\hline 9g composite & 24.47 & 1.63 & 9.00 & 18.63 & 0.28 & 0.58 & 0.60 & 1.46 & 0.79 \\
\hline Control & 17.40 & 1.50 & 4.00 & 17.37 & 0.14 & 0.42 & 0.54 & 1.10 & 0.96 \\
\hline $\mathrm{HSD} \leq 0.05$ & 4.44 & ns & ns & 12.50 & ns & ns & ns & 0.61 & ns \\
\hline
\end{tabular}

ns: Not significantly differently at $\mathrm{P}=0.05$ 
The highest total seedling biomass was observed on seedlings treated with $6 \mathrm{~g}$ of composite fertilizers (6.90 g) and the least had mean biomass of $0.09 \mathrm{~g}$ with seedlings treated with $9 \mathrm{~g}$ of urea and this was significantly different $(P=0.05)$. Albizia zygia seedlings had the highest root/shoot ratio of 4.43 for plants supplied with $6 \mathrm{~g}$ of urea and the least of 0.56 in those treated with $6 \mathrm{~g}$ of composite fertilizer and there were significant differences between treatments at $\mathrm{P}=0.05$.

\section{The effects of fertilizer treatments on the growth of Blighia welwitschii seedlings.}

Seedlings supplied with $9 \mathrm{~g}$ composite fertilizer had highest height $(19.73 \mathrm{~cm})$, collar diameter $(4.30 \mathrm{~cm})$, number of leaves (16), leaf area $\left(140.06 \mathrm{~cm}^{2}\right.$ and total biomass $(12.67 \mathrm{~g})$ Table 3 . The least height, collar diameter, leaf area and total biomass were $13.80 \mathrm{~cm} 2.80 \mathrm{~mm}$ and $86.73 \mathrm{~cm}^{2} 3.46 \mathrm{~g}$ respectively was in seedlings supplied $9 \mathrm{~g}$ of urea. Blighia welwitschii seedlings had the highest mean leaf, stem and root biomass in seedlings treated with $9 \mathrm{~g}$ of composite fertilizer (means of $9.10 \mathrm{~g}, 3.06 \mathrm{~g}$ and $4.51 \mathrm{~g}$ respectively) and the least mean biomass in seedlings treated with $9 \mathrm{~g}$ of urea $(1.16 \mathrm{~g}, 1.12 \mathrm{~g}$ and $1.19 \mathrm{~g}$ respectively), as shown in Table 3. The highest root/shoot ratios between the treatments was observed in seedlings treated with $9 \mathrm{~g}$ of composite (0.55). which not significantly different from the other treatments at $P=0.05$.

\section{The effect of fertilizer treatments on the growth of Lophira alata seedlings}

Seedlings of Lophira alata grown in $9 \mathrm{~g}$ of composite fertilizer had a mean height of $24.97 \mathrm{~cm}$ while those supplied with $9 \mathrm{~g}$ of urea had the shortest seedlings with a mean height of $16.95 \mathrm{~cm}$ and control had $17.4 \mathrm{~cm}$ (Table 4). This increase was significantly different among treatments at $P=0.05$. The highest collar diameter, number of leaves, and leaf area, of L. alata was in seedlings treated with $9 \mathrm{~g}$ composite fertilizer $(1.73 \mathrm{~mm}, 7$, and $21.35 \mathrm{~cm}^{2}$ respectively) and only the leaf area was not significantly different $P=0.05$ from the other treatments. The fertilizer treatments showed significantly difference $(P=0.05)$ in their effects on the total biomass of Lophira alata seedlings, as shown in Table 4. Lophira alata seedling treated with $9 \mathrm{~g}$ composite fertilizer had the highest mean total biomass $(1.53 \mathrm{~g})$ while the least of $0.79 \mathrm{~g}$ was recorded on seedlings supplied with $9 \mathrm{~g}$ of urea fertilizer (Table 4).

\section{The effect of fertilizer treatments on the growth of Pterocarpus soyauxii Seedlings}

Pterocarpus soyauxii seedlings had the greatest height in those plants supplied with $9 \mathrm{~g}$ of composite fertilizers $(18.77 \mathrm{~cm})$ while the least height of $12.33 \mathrm{~cm}$ was noted for seedlings in control, and this was significantly different $(\mathrm{P}=0.05)$ (Table 5) The highest collar diameter was observed on seedling supplied with $9 \mathrm{~g}$ of composite fertilizer and the least in those supplied with $9 \mathrm{~g}$ of urea $(2.50 \mathrm{~mm})$. The largest and smallest leaf areas of Pterocarpus soyuaxii seedlings were observed in those seedlings supplied with $9 \mathrm{~g}$ of composite fertilizers and $9 \mathrm{~g}$ of urea $\left(44.33 \mathrm{~cm}^{2}\right.$ and $26.31 \mathrm{~cm}^{2}$ respectively). This increase was significantly different, at $\mathrm{P}=0.05$ (Table 5). The number of leaves and root dry weight was not significantly different between treatments (Table 5). Total biomass of seedlings showed significant differences $(P=0.05)$ and the highest biomass on seedlings was recorded in those supplied with $9 \mathrm{~g}$ of composite fertilizer $(6.10 \mathrm{~g})$ and the least was noted on seedlings treated with $9 \mathrm{~g}$ of urea $(1.88 \mathrm{~g})$. Seedlings with the highest root/shoot ratio of 0.65 was noted in seedlings supplied with $6 \mathrm{~g}$ of urea and the lowest of 0.33 on seedlings treated with $3 \mathrm{~g}$ of composite fertilizer. 
Table 5. The effects of fertilizer treatments on Pterocarpus soyauxii seedlings

\begin{tabular}{|c|c|c|c|c|c|c|c|c|c|}
\hline \multirow[b]{2}{*}{ Treatment } & \multirow[b]{2}{*}{$\begin{array}{l}\text { Height } \\
\text { (cm) }\end{array}$} & \multirow[b]{2}{*}{$\begin{array}{l}\text { Collar } \\
\text { diameter } \\
(\mathrm{cm})\end{array}$} & \multicolumn{4}{|c|}{ Mean Growth Characteristics } & \multirow[b]{2}{*}{$\begin{array}{l}\text { Dry Weight } \\
\text { Roots (g) }\end{array}$} & \multirow[b]{2}{*}{$\begin{array}{l}\text { Total } \\
\text { biomass } \\
\text { (g) }\end{array}$} & \multirow[b]{2}{*}{$\begin{array}{l}\text { Root/Shoot } \\
\text { Ratio }\end{array}$} \\
\hline & & & $\begin{array}{l}\text { Leaf } \\
\text { number }\end{array}$ & $\begin{array}{l}\text { Leaf } \\
\text { area } \\
\left(\mathrm{cm}^{2}\right)\end{array}$ & $\begin{array}{l}\text { Dry } \\
\text { Weight } \\
\text { leaves(g) }\end{array}$ & $\begin{array}{l}\text { Dry Weight } \\
\text { Stem (g) }\end{array}$ & & & \\
\hline $3 g$ urea & 17.57 & 3.67 & 14.00 & 41.36 & 2.53 & 1.59 & 1.47 & 5.59 & 0.36 \\
\hline $6 g$ urea & 15.76 & 2.80 & 9.00 & 27.06 & 0.85 & 0.84 & 0.76 & 2.45 & 0.65 \\
\hline $9 g$ urea & 13.13 & 2.50 & 6.00 & 26.71 & 0.50 & 0.67 & 0.71 & 1.88 & 0.42 \\
\hline 3g composite & 15.93 & 2.83 & 13.00 & 36.74 & 1.04 & 1.00 & 0.68 & 2.72 & 0.33 \\
\hline $6 \mathrm{~g}$ composite & 16.40 & 3.20 & 11.00 & 37.33 & 1.07 & 0.99 & 1.07 & 3.13 & 0.52 \\
\hline 9g composite & 18.97 & 3.73 & 13.00 & 44.33 & 1.96 & 1.83 & 1.74 & 5.53 & 0.46 \\
\hline Control & 12.33 & 2.93 & 9.00 & 33.33 & 0.73 & 0.67 & 0.77 & 2.17 & 0.54 \\
\hline$H S D \leq 0.05$ & 4.57 & ns & ns & 9.90 & 0.65 & 0.95 & ns & 2.21 & ns \\
\hline
\end{tabular}

ns: Not significantly differently at $\mathrm{P}=0.05$

Table 6. The effect of fertilizer treatment on chlorophyll concentration of seedlings leaves $(\mathrm{ug} / \mathrm{ml})$. 


\begin{tabular}{|c|c|c|c|c|c|c|c|c|c|c|c|c|}
\hline Treatment & \multicolumn{12}{|c|}{ Species } \\
\hline Urea $3 g$ & 23.92 & 8.16 & 32.08 & 23.23 & 7.59 & 30.82 & 14.76 & 5.05 & 19.81 & 23.12 & 7.45 & 30.57 \\
\hline Urea 9g & 17.49 & 5.80 & 23.29 & 22.79 & 5.74 & 28.53 & 9.53 & 3.09 & 12.62 & 18.35 & 6.12 & 24.47 \\
\hline Composite $3 g$ & 24.79 & 8.24 & 33.03 & 24.80 & 8.25 & 33.05 & 21.02 & 7.49 & 28.51 & 22.20 & 7.30 & 29.50 \\
\hline Composite $6 \mathrm{~g}$ & 24.30 & 8.04 & 32.34 & 23.92 & 7.96 & 31.88 & 20.00 & 6.52 & 26.52 & 23.64 & 7.88 & 31.52 \\
\hline Composite $9 \mathrm{~g}$ & 24.61 & 8.17 & 32.78 & 24.36 & 8.09 & 32.45 & 22.77 & 7.55 & 30.32 & 23.88 & 7.90 & 30.03 \\
\hline
\end{tabular}

ns: Not significantly differently at $P=0.05$ 


\section{The effect of fertilizer treatment on chlorophyll concentration of leaves.}

Table 6 illustrates the chlorophyll concentrations in the leaves of the different species under the different fertilizer treatments. Albizia zygia seedlings treated with $3 \mathrm{~g}$ composite fertilizer had the highest total chlorophyll concentration $(33.03 \mathrm{ug} / \mathrm{ml})$ and the lowest was in plants supplied with $9 \mathrm{~g}$ of urea fertilizer $(23.29 \mathrm{ug} / \mathrm{ml})$. Seedlings of Blighia welwitschii had the highest concentration of chlorophyll following treatment with $3 \mathrm{~g}$ of composite fertilizer $(33.05 \mathrm{ug} / \mathrm{ml})$ and the lowest with $9 \mathrm{~g}$ of urea $(28.53 \mathrm{ug} / \mathrm{ml})$. The seedlings of Lophira alata showed the highest chlorophyll concentration with those seedlings treated with $9 \mathrm{~g}$ composite fertilizer ( 30.32 $\mathrm{ug} / \mathrm{ml})$ and the least in seedling supplied with $9 \mathrm{~g}$ of urea $(12.62 \mathrm{ug} / \mathrm{ml})$ and it was significantly different from control $(P=0.05)$. There were no significant differences $P=0.05$ in chlorophyll-a concentration between the other treatments of this species and control. Pterocarapus soyauxii seedlings showed highest chlorophyll concentration with $6 \mathrm{~g}$ of composite fertilizer $(31.52 \mathrm{ug} / \mathrm{ml})$ and lowest in control $(24.46 \mathrm{~s} \mathrm{ug} / \mathrm{ml})$ and this not significantly from the other treatments.

\section{Discussion}

\section{The effect of fertilizer application on seedling growth}

The major morphological criteria used to grade seedling quality in the nursery include shoot height, collar diameter, leaf area, leaf number, leaf chlorophyll and seedling biomass (Hoque et al., 2004a). In this study, Composite fertilizer affected growth more positively than urea as the highest increments were observed in seedlings treated with composite fertilizer though some of the effects were not significantly different from the control. The most likely explanation is that, composite fertilizers contain most of the nutrients needed for plant growth. High urea levels $(6 \mathrm{~g}$ and $9 \mathrm{~g}$ ) showed poor growth in heights in A.zygia seedlings. This might be as a result of toxicity, which might inhibit uptake rate of plant nutrients and consequently retarding their growth. This is in line with observations made by Ong et al., (2004) who reported poor growth in seedling height of Shorea following treatment with high urea level $(6 \mathrm{~g})$. Albizia zygia seedlings demonstrated significantly highest height increment when supplied with $9 \mathrm{~g}$ of composite fertilizer. Albizia zygia is a nitrogen fixing plant and the supply of composite fertilizers also improves on the nutrient pool of the soil thereby enhancing positively on maximum growth in height.

Fertilizers significantly affected the increase in height of $B$. welwitschii seedlings. This is consistent with the findings of Hoque et al. (2004a) who found significant height increase in seedlings of Michelia champaca after $\mathrm{N}$ and $\mathrm{P}$ fertilization. Probably, soil resources might be limiting under these treatments. However high doses of $\mathrm{P}$ and especially $\mathrm{N}$ decrease growth in height as it affects the uptake of other nutrients (Jose, 2003). Pterocarpus soyauxii seedlings showed significant growth in height to all fertilizer treatments which shows that fertilization stimulated the growth of this species. The high rate of urea fertilization did not have much negative effect when compared with the other species which might be due genetic potentials of this species to stress.

The leaf areas of the seedlings were low at high urea fertilizer levels (6 g and $9 \mathrm{~g})$ in B. welwitschii, L. alata and $P$. soyauxii, though not significantly different from the control. Very high levels of urea fertilizer are toxic to the plant and thereby reducing growth performance. Profuse vegetative and foliar growth is often an indication of nitrate fertilization; hence the lack of significant differences might indicate that the nitrate concentration in the different treatments was just enough for normal plant growth. This is in conformity with findings of Hoque et al., (2004 b), who observed no significant increments in leaf area following the addition of $\mathrm{N}$ and $\mathrm{P}$ fertilizers on Anthocephalus chinensis.

All species had an increase in collar diameter following treatment with $3 \mathrm{~g}$ and $6 \mathrm{~g}$ of composite fertilizers. This might be an indication that between $3 \mathrm{~g}$ and $6 \mathrm{~g}$ of composite fertilizer, may have enhance the growth in diameter, and above $6 \mathrm{~g}$, there might have been some inhibition of radial growth. These findings are contrary to 
those of Pinkard et al., (2007) who observed a general significant increase in collar diameter of Eucalyptus globolus in response to all levels of $N$ and NP fertilizers ( $(0,25,50,100$ and $250 \mathrm{ppm})$. Three grams of urea produced the highest number of leaves in A,zygia and $9 \mathrm{~g}$ of composite fertilizer gave the highest leaf number in all other species. Nitrogen is essential for foliage formation, and nitrogen fertilization below toxic levels would result to profuse foliage growth. These findings are similar to those of Gbadamosi (2006) who reported a progressive decrease in the number of leaves of Enantia chlorantha as the dose of NPK was increased.

The insignificant difference in plant biomass with fertilization for A. zygia, B. welwitschii and L. alata might imply that fertilization did not effectively alter net primary productivity of these species. The biomass of $P$. soyauxii seedlings was increased by the different levels of fertilizers. Biomass is an estimate of net primary production as well as dependent on other plant parameters such as wood density. This is in conformity to findings of Berger and Gerhard (2001) who observed that all $\mathrm{N}$-fertilization types ( $, \mathrm{P}, \mathrm{K}, \mathrm{Mg}$ or $\mathrm{N}, \mathrm{P}, \mathrm{K}, \mathrm{Mg}, \mathrm{Ca}$ ) increased the biomass production of Quercus petraea irrespective of soil type. The root/shoot ratios in the different treatments were less than 1.0, but for 6 and $9 \mathrm{~g}$ of urea on A.zygia that gave values greater than 1.00. This indicated more carbon sink in the latter root than the shoots. This is probably an adaptation strategy to explore more soil resources for growth of this species. The low root/shoot ratio of less than 1.0 of the other species indicated more carbon sink in the shoots than the roots and also an adaptation to withstand the mechanical effects of wind on the shoots. This observation was noted by Ong et al., (2004), who reported low root/shoot ratios in fertilized shorea seedlings.

\section{The effect of fertilizers on the leaf Chlorophyll concentrations of seedlings.}

Nitrogen promote the biosynthesis of active photosynthetic pigments by increasing the number of stromal and thylakoid proteins in the leaves (Cooke et al.,2005) and also the chloroplast during leaf growth (Li et al., 2017). Appropriate fertilizer application showed an increase in the chlorophyll content than control. A similar observation was noted by Prsa et al (2007) for the "Golden delicious" apple. Increase in chlorophyll content with fertilization have also been reported by Razaq et al (2017) for Acer mono seedlings, Li et al (2017) for Populus species and Abdullahi et al (2012) for Vitellaria paradoxa seedlings. There was no significant increase in chlorophyll content for three of the species and their control which might be probably that, the existing pool of nitrogen in non-fertilized seedlings did not limit the enzyme rubisco (RuBP carboxylase/oxygenase) activity and efficiency. It was noted the application of $9 \mathrm{~g}$ of urea fertilizer affected negatively the growth and chlorophyll concentrations of the four species of tree seedlings. This might be as a result of excess nitrogen, which is noted to shortens life-span of leaves and increase their susceptibility to diseases (vanLelyveld et al., 1990). Differential species responses to fertilization suggest that certain species may be better able to take advantage of changes in nutrient availability, which play an important role in regeneration dynamics in the forest as species are better able to utilize moderate increases in nutrient availability to enhance spectral absorbance. This may frequently achieve a positive carbon balance in light-limited environments.

\section{CONCLUSION}

Composite fertilizer was the best fertilizer given that it gave the highest seedling increments in all the parameters studied though some of the increments were not significantly different from those of the control. Three grams of urea produced the greatest number of leaves in A. zygia. Albizia zygia and Blighia welwitschii, seedlings had the best results in soil treated with $6 \mathrm{~g}$ of composite fertilizer, while Lophira alata and Pterocarpus soyauxii seedlings showed best growth in soils treated with $9 \mathrm{~g}$ of composite fertilizers for all the other parameters. Leaf chlorophyll concentration increased with fertilizer application in especially for Lophira alata seedlings.

Fertilizer-treated seedlings are recommended for planting into the field when the right type and amount of fertilizer is used. Even when fertilized seedlings do not portray significant performances than unfertilized ones, 
they establish better in the field since they have reserved nutrient resources. These results therefore indicate that, optimum soil fertilization is essential for the production of high-quality tree seedlings.

Conflict of interest: There is no conflict of interest.

Authors contributions: This work was carried in collaboration between authors. The author Egbe EA designed the study, wrote the protocol, did the data analysis and reviewed the draft manuscript; Tata BL did the data collection and wrote the first draft manuscript; Enow EA drew the graphs, tables and literature review. All the authors read and approved the final manuscript.

\section{REFERENCES}

1. Abdullahi I. N., Chuwang P. Z., and Isah A. D. (2012). Effect of biofertilizer on the growth of Vitellaria paradoxa seedlings. Journal of Research in Environment and Toxicology. 1 (11): 294- 297.

2. Balanle-ojo O. T., Afolabi J. O., Ogunsyi A. O., Ogunade J.O and Morankinyo D. A. (2015). Effect of graded levels of organic and inorganic fertilizers as amendment to potted seedlings of Artocarpus heterophyllus. Jr. Forestry Research and Mgt. 14 (2): 64- 67

3. Berger, T.W. and Gerhard, M. (2001). Response of Quercus petraea seedlings to nitrogen fertilization. Forest Ecology and Management. 149(1-3): 1- 14.

4. Boggs, J. L. Tsegaye, T. D. Coleman, T. L. Reddy, K. C. and Fahsi, A. (2003). Relationship Between Hyperspectral Reflectance, Soil Nitrate-Nitrogen, Cotton Leaf Chlorophyll, and Cotton Yield: A Step Toward Precision Agriculture. Journal of Sustainable Agriculture 22(3) 5-16.

5. Cooke J. E., Martin T. A and Davis J. M (2005). Shot-term physiological and developmental responses to nitrogen availability in hybrid poplar. New Phytologist 167(1)41- 52

6. Côomes, O., Barham, B. and Takasaki. Y. (2008) "Targeting Conservation- Development Initiatives in Tropical Forests: Insights from Analyses of Rainforest Use and Economic Reliance among Amazonian Peasants." Ecological Economics 51:11-21.

7. De Capua, J. (2005) The Congo Basin Forest Summit held February 4th and 5th in Brazzaville. Report on Congo Basin Washington, USA 11p.

8. Egbe E. A., Tabot P. T and Fonge B. A. (2012a). Ethnobotany and prioritization of some selected tree species in Southwestern Cameroon. Jr. of Ethnobotany Research and Application. 10: 235 - 246.

9. Egbe E. A., Chuyong GB., Fonge BA., Tata BL. and Tabot P. (2012b). The effects of different concentration of indole-3-butyric acid (IBA) on leafy stem cuttings of four tropical timber species. Journal of Horticulture and Forestry 4(5) 85-91

10. FAO, (2005). Global forest resource assessment 2005. Fifteen key findings. Food and Agricultural Organization of the United Nations report. Rome.

11. Focho D. A., Bechem E., Egbe A., Fongod A. G., Fonge B. A. and Njoh R. N (2012). The effect of organic and inorganic fertilizers on the growth characteristics of Khaya ivorensis (African Mohogany) in nursery. African Jr. of Plant Science 5(12) 722-729 
12. Gbadamosi, A.E (2006). Fertilizer response in seedlings of medicinal Enantia chlorantha. Tropical and Subtropical Ecosystems 6:111-115.

13. Groves, R.H. and Keraitis, K. (1976). Survival and growth of seedlings of three Sclerophyll species at high levels of phosphorus and nitrogen. Australian Journal of Botany 24(6): $681-690$

14. Harper J. E. (1994). Soil and symbiotic nitrogen requirement for optimum soybean production. Crop Science 14 (2): $225-260$

15. Hoque, A.T.M.R Hossain, M.K., Mohiuddin, M.and Hoque, M.M. (2004a). Effect of inorganic fertilizers on initial growth performance of Michelia champaca seedlings in the nursery. Journal of Biological Sciences 4:489-497

16. Hoque, A.T.M.R., Hossain, M.K., Mohiuddio, M. and Hoque, M.M. (2004b). Effect of inorganic fertilizer on the initial growth performance of Anthocephalus chinensis seedlings in the nursery. Journal of Applied Sciences 4(3):477-485

17. Jose L. M. (2003). Nitrogen and phosphorus resorption in trees of Neotropical rainforest. Journal of Tropical Ecology 19:465-468

18. Kanwar L., Sahrawat K., Murthy V. S., Shirisha K and Wani S. P. (2014). Quality control in soil testing using internal standard, temporal variability in organic carbon and extractable nutrient elements. Communications in Soil Science and Plant Analysis. 45: 1162- 1165.

19. Li G.L., Zhu Y., Wang J.X., Liu J.J and Dumroese R.K. (2014). Combined effect of preharding and fall fertilization on nitrogen translocation and storage in Quercus varcabilis seedlings. European Jr. of Forest Research 123 (6): 983 - 992.

20. Li H., Li M., Luo J., Cao X., Qu L., Gai Y et al (2012). N-fertilization has different effect on the growth, carbon and nitrogen physiology and wood properties of slow and fast growing Populus species. Jr. of Experimental Botany. 63 (17): 6173-6185)

21. Ong, K. Lim, M.T and Labit, S (2004). Growth and photosynthetic response of Shorea platyclados seedlings to nitrogen application. In H. Aminah., S. Ani, H.C. Sim and B. Krishnapillay, Eds. Proceedings of the seventh round table conference on dipterocarps, Asia Pacific Association of Forestry Research Institutions, Kuala Lumpur, pp 89-100.

22. Pinkard, E.A., Ballie, C., Patel, V. and Mohammed, C.L. (2007). Effects of fertilizing with nitrogen and phosphorus on growth and crown condition of Eucalyptus globolus Labill. experiencing insect defoliation. Forest ecology and management. 231:131-137.

23. Prsa l., Stampar F., Vodnik D., Veberic R. (2007). Influence of nitrogen on leaf chlorophyll content and photosynthesis of "Golden Delicious" apple. Acta Agriculturae Scandinavica 57 (3): 283 -289

24. Razaq M., Zhang P., Shen $\mathrm{H}$ and Salahuddin. (2017). Influence of nitrogen and phosphorus on the growth and root morphology of Acer mono. PLOS ONE. 12(2): e0171321

25. Repetto R (1990) Deforestation in the tropics. Scientific American 262(4):36-42.

26. Uscola M., Salifu K F., Oliet J.A., and Jacobs D.F. (2015). An exponential fertilization dose response model to promote restoration of the Mediterranean oak (Quercus ilex). New Forests 46(5): 785 - 812. 
27. vanLelyveld L. J., Smith B. L and Frazer C. (1990). Nitrogen fertilization of Tea: Effect on chlorophyll and quality parameters of processed black tea. ActaHorticulturae 275: 483- 488.

28. Villar-salvador P., Uscola M., and Jacobs D.F. (2015). The role of stored carbohydrates and nitrogen in the growth and stress tolerance of plant forest trees. New Forest 46 (5): 813- 939.

29. Wang J., Li G., Liu J., Shi W., and Liu Y. (2015). Both nursery and field performance determine suitable nitrogen supply of nursery grown exponentially fertilized Chinese pine. Silva Fennica 49(3)

30. Well M. L. ed (2007). Southeastern Pecan grower handbook. Pub. 1327 University of Georgia Cooperative Extension Service, Athens Georgia.

31. Zhang, Z and Amaral, M.C.E. "Ochnaceae". In Flora of China (1992) Vol. 12. Published by Science Press (Beijing) and Missouri Botanical Garden Press.

32. Zhao D., Kane M., Border B., Hamson M. (2008). Pine growth response to different site-preparation methods with or without post-plant herbaceous weed control on North Florida`s lower coastal plain. Forest Ecology and Management 255 (7): $2512-2523$ 